\title{
Application of ecological technology for removal of COD, nitrogen and phosphorus from piggery wastewater after biogas production technology
}

\author{
Úng dụng công nghệ sinh thái để xủi lý COD, Nito và Phôtpho trong nuớc thải \\ chăn nuôi lọn sau công nghệ Biogas
}

Research article

Vu, Thi Nguyet*1; Tran, Van Tua ${ }^{1}$; Dang, Dinh Kim ${ }^{1}$; Bui, Thi Kim Anh ${ }^{1}$; Vu, Hai Yen ${ }^{2}$

${ }^{1}$ Institute of Environmental Technology, Vietnam Academy of Science and Technology, 18 Hoang Quoc Viet, Hanoi, Vietnam; ${ }^{2}$ ThuyLoi University, 175 Tay Son, Dong Da, Hanoi, Vietnam.

\begin{abstract}
Despite a positive contribution to economic - social development, the growth of piggeries has caused heavily environmental pollution. Currently, treated wastewater of pig farms unfortunately does not meet the national discharge standards yet. This paper presents some research results on the removing COD, nitrogen and phosphorus in piggery wastewater after anaerobic (biogas) process at pilot scale by the combined system using Phragmites australis, Cyperus alternifolius, Vetiveria zizanioides and Eichhornia crassipes. The experimental results showed that the wastewater loading rate of $47.35 \mathrm{l} / \mathrm{m}^{2}$.day with initial concentrations of $203.24 \mathrm{mg} \mathrm{COD} / 1,111.94 \mathrm{mgTN} / 1$ and 13.61 $\mathrm{mgTP} / \mathrm{l}$ gave removal efficiency of $71.66 \%, 79.26 \%$ and $69.65 \%$, respectively. Thus, the removed quantity of total nitrogen (TN) and total phosphorus (TP) was of $4201.35 \mathrm{mg} \mathrm{TN} / \mathrm{m}^{2}$.day và $448.76 \mathrm{mg} \mathrm{TP} / \mathrm{m}^{2}$.day. The obtained results indicated that the flow wetland system, using Phragmites australis, Cyperus alternifolius, Vetiveria zizanioides and Eichhornia crassipes has a rather high COD, TN and TP removal efficiency with simple operation so that it could be feasible if applied for treating pig wastewater. However, the system should be functioned longer for taking data and for evaluating its stability.
\end{abstract}

Mặc dù có nhũng đóng góp tích cưc cho sự phát triển kinh tế - xã hội, việc phát triển chăn nuôi lợn đã gây ô nhiễm môi truờng nghiêm trọng. Hiện nay, nuớc thải chăn nuôi lọn tù các co sở chăn nuôi sau xử lý vẫn chuva đáp ứng được các tiêu chuẩn thải của quốc gia và tiêu chuẩn ngành. Bài báo này trình bày kết quả nghiên cứu về khả năng loại bỏ COD, nito $(N)$ và phôtpho (P) trong nuớc thải chăn nuôi lọn đã qua xử lý bằng hầm biogas của hệ thống phối hợp cây Sậy, Thủy Trúc, cỏ Vetiver và Bèo Tây ở qui mô pilot. Kết quả thưc nghiệm ở tải luợng 47,35 l/ $\mathrm{m}^{2}$.ngày, với $C O D$, tổng nito (TN) và tổng phôtpho (TP) đầu vào trung bình là 203,24 mg/l, 111,94 mg/l và 13,61 mg/l, tuơng úng, thì hiệu suất xủ̉ lý lần luợt là 71,66\%; 79,26\% và $69,65 \%$. Nhu vậy luợng $T N$ và TP loại bỏ là $4201,35 \mathrm{mgN} / \mathrm{m} 2$.ngày và $448,76 \mathrm{mgP} / \mathrm{m} 2$.ngày. Kết quả nhận được cho thấy hệ thống sủ dụng cây Sây, Thủy Trúc, cỏ Vetiver và Bèo Tây có hiệu quả loại bỏ COD, TN và TP khá cao trong khi vận hành đơn giản nên có triển vọng áp dụng trong điều kiện thực tế để xử lý nước thải chăn nuôi lợn. Tuy nhiên để đánh giá tính ổn định, hệ thống cần được hoạt động với thời gian lâu dài hơn.

Keywords: $\quad$ ecotechnology, Phragmites australis, Cyperus alternifolius, Eichhornia crassipes, Vetiveria zizanioides, piggery wastewater 


\section{Introduction}

In Vietnam, the piggeries are considered to be the strength of the agricultural sector. Currently, the household pig farming tends to fall while livestock farms increase rapidly and create competitiveness in the market. However, the waste generated from pig farming operations is a matter of concern.

Currently, popular treatment of farm animal waste is through biogas system, but this system can treat only 50$70 \%$ of farm waste [6]. Some farms have biogas and waste treatment systems but the systems operate ineffectively, waste has not been treated thoroughly. According to Vincen Porphyre et al (2006) [9], the use of biogas tank in the farms is convenient for using waste and exploiting energy sources but wastewater after Biogas tanks has still many pollutants such as $\mathrm{N}$ and $\mathrm{P}$ and needs to be treated before being discharged into the environment.

To solve the above-mentioned problem, the combination of methods for livestock wastewater treatment with ecological technology using aquatic plants was studied, applied and obtained positive results by many authors. Ecological technology using aquatic plants as Eichhornia crassipes, Pistia stratiotes, Ipomoea aquatica, Phragmites australis, Vetiveria zizanioides... for piggery wastewater treatment has many advantages compared to the general wastewater treatment systems, including reduction of COD, nitrogen and phosphorus to acceptable levels in terms of the environment. This method is very environmentally friendly, inexpensive, easy to operate and in accordance with the actual conditions of Vietnam $[2,7]$.

The experimental combination of Phragmites australis, Cyperus alternifolius, Eichhornia crassipe and Vetiveria zizanioides to remove COD, TN, TP from piggery wastewater after biogas technology was conducted to assess the effectiveness of the process and creates the scientific basis for applying these aquatic plants in pollution treatment at pilot scale.

\section{Materials and research methods}

\subsection{Research plants}

Reed (Phragmites australis Cav.) is a large perennial grass belonging to family Poaceae, distributed in wetlands throughout temperate and tropical regions of the world. Reed used for the experiment was collected from the Red River bank and planted in the Co Nhue experimental base, Tu Liem, Hanoi. Plants used for experiments were juvenile with plant density of $15 \mathrm{~cm}$ x $20 \mathrm{~cm}$.

Umbrella plant (Cyperus alternifolius Linn) lives in tropical, subtropical and temperate regions with optimal ambient temperature from $12-30^{\circ} \mathrm{C}, \mathrm{pH} 4-8$. The plants used for experiments were with strong growth, and planted at a density of $15 \mathrm{~cm} \times 20 \mathrm{~cm}$.

Water hyacinth (Eichhornia crassipes (Mart.) Solms), belongs to Pontederiaceae [1]. Eichhornia crassipes used for experiments were juvenile with strong growth, occupying $4 / 5$ of experimental water surface.

Vetiver grass (Vetiveria zizanioides) belonging to Grami$n a e$, is widely distributed in the tropics. The grass used for experiments were grown in the Co Nhue experimental base, Tu Liem, Hanoi. Strongly growing vetiver grass were collected for experiment and planted at a density of $15 \mathrm{~cm}$ $\mathrm{x} 20 \mathrm{~cm}$.

\subsection{Piggery wastewater}

Wastewater after anaerobic digestive processes was collected from Thuy Phuong Pig Research Center, Tu Liem, Hanoi. The characteristics of the wastewater varied in a range of $\mathrm{pH} 7.83$ - 8.2; TSS $5460 \mathrm{mg} / 1$ - $9450 \mathrm{mg} / 1$; COD 775.53 - $1985.98 \mathrm{mg} / \mathrm{l}$; TN 744.59 - $1114.24 \mathrm{mg} / \mathrm{l}$; TP $50.04 \mathrm{mg} / 1$ - $115.24 \mathrm{mg} / 1$. Among various forms of nitrogen, $\mathrm{NH}_{4}{ }^{+}$was main form $(703.82 \mathrm{mg} / 1-892.11 \mathrm{mg} / \mathrm{l})$ while $\left.\mathrm{NO}_{3}\right\urcorner$ was negligible $(0.65 \mathrm{mg} / 1$ to $1.68 \mathrm{mg} / \mathrm{l})$. We conducted analysis of wastewater quality and based on resistance of investigated plants, treatment efficiency and the required output water quality, we adjusted the amount of $\mathrm{N}$ and $P$ in the range of $10-15 \mathrm{mg} / 1$ and $90-120 \mathrm{mg} / 1$., respectively.

The experiments were conducted in 2015 at the Department of Environmental Hydrobiology, Institute of Environmental Technology, Vietnam Academy of Science and Technology.

\subsection{Pilot scale experiments}

The experiment consisted of 4 tanks with alternative systems having Phragmites australis (surface flow system, Tank 1); Cyperus alternifolius and Vetiveria zizanioides (Floating plant system, Tank 2); Eichhornia crassipes (Floating plant system, Tank 3); Vetiveria zizanioides (submerged flow system. Tank 4) (Fig.1.1). The duration of the experiment was of 6 weeks.

The size of each tank was:

$\mathrm{D} \times \mathrm{W} \times \mathrm{H}=44 \mathrm{~cm} \times 30 \mathrm{~cm} \times 30 \mathrm{~cm}$

Where:

- Volume of Phragmites australis growing tank 1: (Hs $\mathrm{x}$ Ds $\times$ Rs) $=28 \mathrm{~cm} \times 44 \mathrm{~cm} \times 30 \mathrm{~cm}$, equivalent to 36.96 liters. In this tank soil was added with a height of $15 \mathrm{~cm}$, so the volume of remaining water was only of 17.16 liters.

- Volume of Cyperus alternifolius and Vetiveria zizanioides growing tank 2 was of $26 \mathrm{~cm} \mathrm{x} 44 \mathrm{~cm} \times 30 \mathrm{~cm}$, equivalent to 34.32 liters.

- Volume of Eichhornia crassipes growing tank 3 was of $26 \mathrm{~cm} \times 44 \mathrm{~cm} \times 30 \mathrm{~cm}$, equivalent to 34.32 liters.

- Volume of Vetiveria zizanioides growing tank 4 (submerged flow) was of $28 \mathrm{~cm} \times 44 \mathrm{~cm} \mathrm{x} 30 \mathrm{~cm}$, equivalent to 36.96 liters. Gravel was added so the volume of final water was 10.3 liters. 


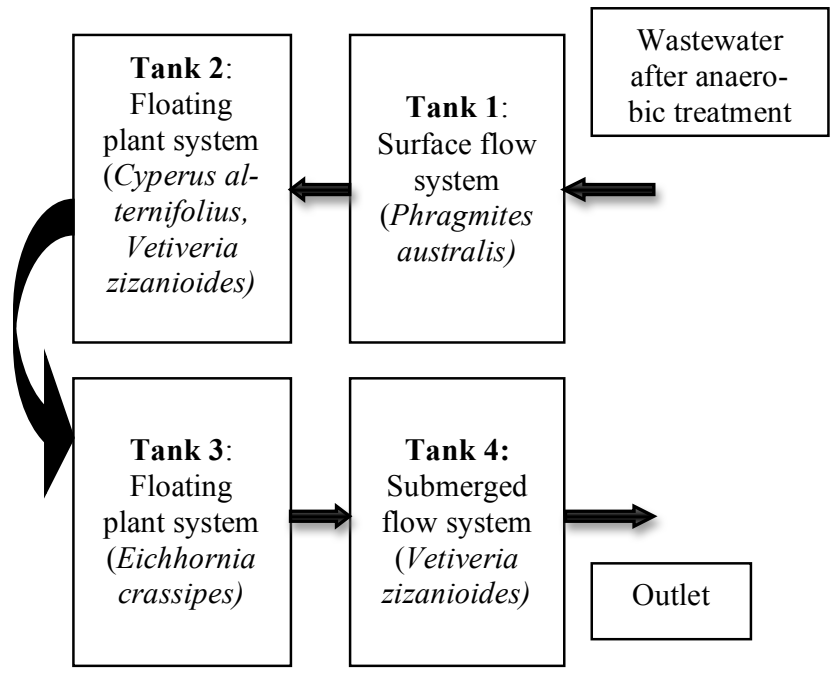

Figure 1. Experimental diagram of the combined system of reed, umbrella plant, water hyacinth and vetiver grass at pilot scale.

Operation of the system: Wastewater was pumped from the storage tank into the system and flows through 4 tanks step by step like in Figure 1.

\subsection{Analysis method}

The parameters $\mathrm{NH}_{4}^{+}, \mathrm{NO}_{3}{ }^{-}, \mathrm{NO}_{2}{ }^{-}, \mathrm{PO}_{4}{ }^{3-}, \mathrm{TP}, \mathrm{TN}$ and COD were determined according to the Standard methods (APHA, 1995) and measured on Spectrophotometer UVVis 2450, Shimadzu-Japan.

\section{Results and discussions}

\subsection{COD removal efficiency}

COD removal efficiency from piggery wastewater in the combined system of Phragmites australis, Cyperus alternifolius, Eichhornia crassipes and Vetiveria zizanioides with the wastewater load of $47.351 / \mathrm{m}^{2} . \mathrm{d}$ is shown in Figure 2.

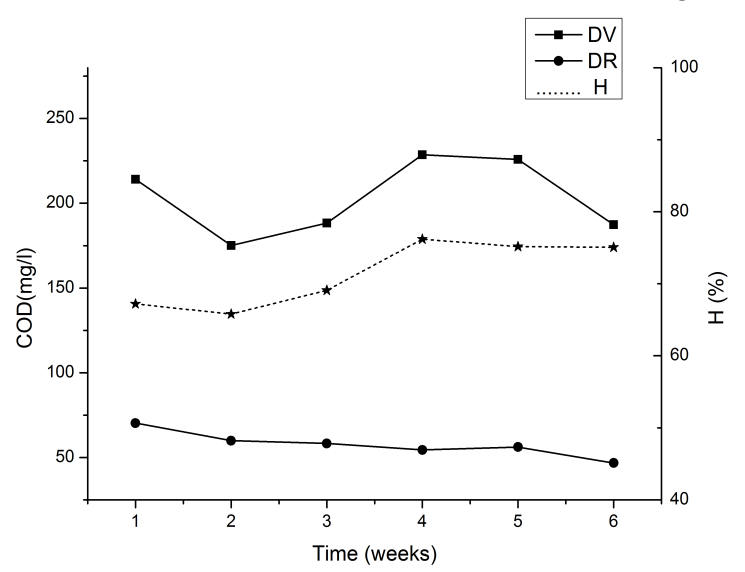

Figure 2. COD removal of the combined system of Phragmites australis, Cyperus alternifolius, Eichhornia crassipes and Vetiveria zizanioides with the wastewater load of $47.35 \mathrm{l} / \mathrm{m}^{2}$.d. \{DV-inlet, DR-outlet, H -treatment efficiency\}.

The initial average COD concentration was of $203.24 \mathrm{mg} / 1$ (in the range of $175.05 \mathrm{mg} / 1$ to $228.56 \mathrm{mg} / \mathrm{l}$ ) and it reduced to $140.44 \mathrm{mg} / \mathrm{l}$ after discharging from Phragmites australis tank. So the COD removal efficiency of Phragmites australis tank was of $30.9 \%$. When flowing through the floating plant system 2, the average COD remained $104.1 \mathrm{mg} / \mathrm{l}$. After tank 3, the average COD was of $78.4 \mathrm{mg} / \mathrm{l}$. Thus, separately floating plant system removed $25.88 \%$ COD, Eichhornia crassipes system (tank 3 ) removed $24.68 \%$ COD and the whole combined system removed $71.66 \%$ COD (ranging from $65.79 \%$ to $76.19 \%$ ). So when wastewater went out of the tank 4 , the remaining average COD was of $57.61 \mathrm{mg} / 1$ (ranging from 46.73 to $70.25 \mathrm{mg} / \mathrm{l}$ ). The final COD met the level A of National technical regulation on industrial wastewater, QCVN 40:2011/MONRE.

\subsection{Nitrogen removal efficiency}

Nitrogen removal efficiency from piggery wastewater of the combined system of Phragmites australis, Cyperus alternifolius, Eichhornia crassipes and Vetiveria zizanioides with the wastewater load of $47.351 / \mathrm{m}^{2}$.d is shown in Figure 3.

The inlet average TN concentration was $111.94 \mathrm{mg} / \mathrm{l}$ (in the range of $107.58 \mathrm{mg} / \mathrm{l}$ to $116.23 \mathrm{mg} / \mathrm{l}$ ) and it was 72.76 $\mathrm{mg} / \mathrm{l}$ after out of Phragmites australis tank 1 . So the TN removal efficiency of Phragmites australis tank was $35.07 \%$. When flowing through the tank 2, the TN remained $52.41 \mathrm{mg} / \mathrm{l}$, equivalent to treatment efficiency of $27.9 \%$. After the tank 3, the average TN was $35.12 \mathrm{mg} / \mathrm{l}$ and the treatment efficiency achieved $32.99 \%$. The average TN after going out of the combined treatment system was $23.21 \mathrm{mg} / 1$ (ranging from $21.09 \mathrm{mg} / 1$ to 24.82 $\mathrm{mg} / \mathrm{l}$ ). So the TN removal efficiency of the whole treatment system reached $79.26 \%$ (ranging from $77.26 \mathrm{mg} / 1$ to 80.31 $\mathrm{mg} / \mathrm{l} \%$ ). The outlet TN met the level B of QCVN 40:2011/MONRE.

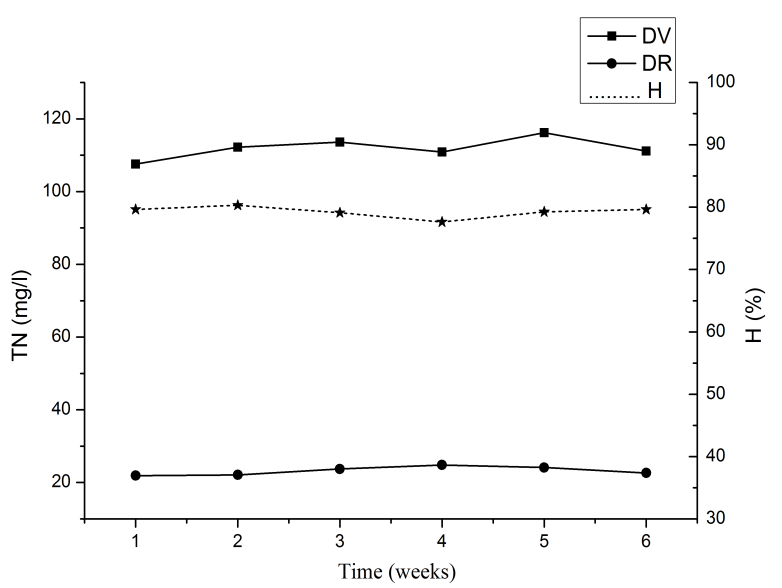

Figure 3. Nitrogen removal of the combined system of Phragmites australis, Cyperus alternifolius, Eichhornia crassipes and Vetiveria zizanioides with the wastewater load of $47.35 \mathrm{l} / \mathrm{m}^{2}$.d. $\{$ DV-inlet, DR- outlet, H -treatment efficiency\}.

\subsection{Phosphorus removal efficiency}

Phosphorus removal efficiency from piggery wastewater of the combined system of Phragmites australis, Cyperus alternifolius, Eichhornia crassipes and Vetiveria zizanioides with the wastewater load of $47.351 / \mathrm{m}^{2} . \mathrm{d}$ is presented in Figure 4. 
The average TP concentration of inlet wastewater was $13.61 \mathrm{mg} / 1$ (ranging from $11.54 \mathrm{mg} / 1$ to $15.83 \mathrm{mg} / \mathrm{l}$ ). After Phragmites australis tank, the remaining TP concentration was $9.53 \mathrm{mg} / \mathrm{l}$, equivalent to the treatment efficiency of $30.0 \%$. After flowing through tank 2 , the TP concentration was $7.18 \mathrm{mg} / 1$, equivalent to treatment efficiency of $24.6 \%$. After tank 3, the TP concentration was $5.36 \mathrm{mg} / \mathrm{l}$ and the treatment efficiency got $25.3 \%$. The TP concentration in outlet wastewater was $4.13 \mathrm{mg} / \mathrm{l}$ (ranging from $3.7 \mathrm{mg} / 1$ to $4.58 \mathrm{mg} / \mathrm{l})$. The TP removal efficiency of the whole treatment system reached $69.65 \%$ (ranging from $67.94 \%$ to $72.61 \%$ ). The treated wastewater met the level B of QCVN 40:2011/MONRE.

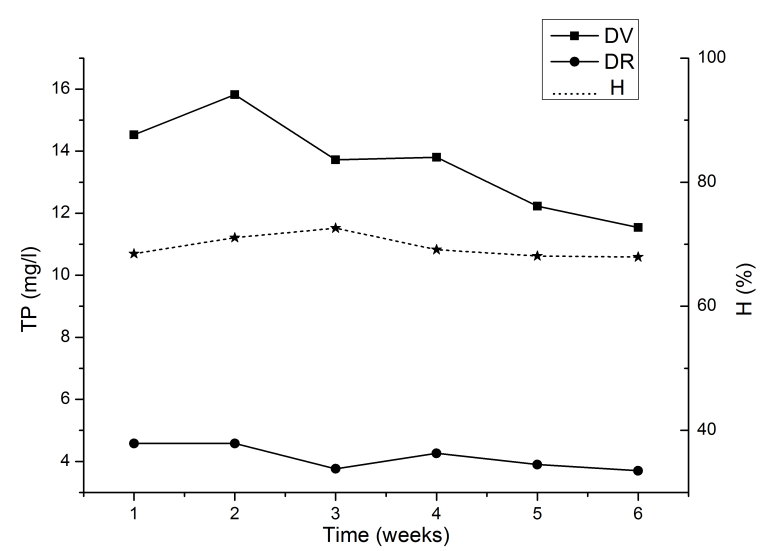

Figure 4. Phosphorus removal of the combined system of Phragmites australis, Cyperus alternifolius, Eichhornia crassipes and Vetiveria zizanioides with the wastewater load of $47.35 \mathrm{l} / \mathrm{m}^{2}$.d. \{DV-inlet, DR -outlet, H -treatment efficiency\}

Generally, the combination of the surface flow system (Phragmites australis) - tank 1, the floating plant system (Cyperus alternifolius, Vetiveria zizanioides and Eichhornia crassipes), tank 2 and 3, and the submerged flow system (Vetiveria zizanioides), tank 4 had good treatment efficiency. The treated wastewater met the level B of QCVN 40:2011/MONRE in terms of COD, TN and TP.

The obtained results were similar to that of domestic and international publications. So, Prapa Sohsalam et al (2008) studied possibility of seafood processing wastewater treatment by the surface flow system using sedge, canna, and typha. The treatment system was loaded 2 times with diluted wastewater. The system with retention time 5 days removed $91-99 \% \mathrm{BOD}, 52-90 \% \mathrm{SS}, 72-92 \% \mathrm{TN}$ and $72-$ $77 \%$ TP [5].

Rory Harrington and Robert McInnes (2009) used ecological technology with aquatic plants in combination with other technologies in livestock wastewater management achieved social, economic and environmental targets. Eight-year operating results of 12 such systems in Ireland demonstrated the effectiveness and sustainability of this type of technology. Total phosphorus and ammonium removal efficiency was of 95 and $98 \%$, respectively [6].

In Vietnam, Dang Nhu Xuyen et al (2005) studied piggery wastewater treatment at pilot scale by combined system of
UASB with aquatic plant Eichhornia crassipes. The system removed $70 \% \mathrm{~N}-\mathrm{NH}_{4}{ }^{+}, 58-65 \% \mathrm{PO}_{4}{ }^{3-}$ and maintained $\mathrm{pH}$ stable in range from 6.8 to 6.9 [4].

Truong Thi Nga et al (2010) studied livestock wastewater treatment by Enydra fluctuans Lour and Eichhornia crassipes in Hau Giang. The results showed that Enydra fluctuans Lour removed $53.60 \%$ TN, 33.56\% TP while Eichhornia crassipes reduced $64.36 \% \mathrm{TN}$ and $42.54 \% \mathrm{TP}$. The author also showed that these plants have been adapted to this wastewater environment [3].

Tran Van Tua et al (2013) investigated the piggery wastewater treatment by surface flow technology. The obtained results showed that the Phragmites australis removed $53.52 \% \mathrm{TN}$ and $42.83 \% \mathrm{TP}$ at the load rate of 50 $1 / \mathrm{m}^{2}$.d [8], while Vu Thi Nguyet et al (2015) studied the piggery wastewater treatment by surface flow technology using Eichhornia crassipes. The results indicated that at the load rate of $501 / \mathrm{m}^{2} . \mathrm{d}$, Phragmites australis treated $65.79 \% \mathrm{TN}$ and $55.19 \%$ TP [10].

\section{Conclusion}

The obtained research results concerning the application of the combined system using 4 aquatic plants for removing $\mathrm{COD}, \mathrm{N}$ and $\mathrm{P}$ from piggery wastewater after biogas production technology have shown:

The combined system of Phragmites australis, Cyperus alternifolius, Eichhornia crassipes and Vetiveria zizanioides proved to be highly efficient in removing COD, $\mathrm{N}$ and $\mathrm{P}$. At the load rate of $47.351 / \mathrm{m}^{2} . \mathrm{d}$, inlet COD, TN and TP concentration were $203.24 \mathrm{mg} / \mathrm{l}, 111.94 \mathrm{mg} / \mathrm{l}$ and 13.61 $\mathrm{mg} / \mathrm{l}$, respectively, the treatment efficiency of COD, TN and TP got $71.66 \%, 79.26 \%$ and $69.65 \%$, respectively. TN and TP loaded in the system with $5300.49 \mathrm{mgN} / \mathrm{m}^{2} . \mathrm{d}$ and $644.32 \mathrm{mgP} / \mathrm{m}^{2} . \mathrm{d}$, respectively, and the system removed $4201.35 \mathrm{mgN} / \mathrm{m}^{2} . \mathrm{d}$ and $448.76 \mathrm{mgP} / \mathrm{m}^{2}$.d. The treated wastewater quality met the level $B$ of QCVN 40:2011/MONRE in terms of COD, TN and TP.

The application of the combined system using Phragmites australis, Cyperus alternifolius, Eichhornia crassipes and Vetiveria zizanioides to remove COD, $\mathrm{N}$ and $\mathrm{P}$ from piggery wastewater is feasible and promising to be enlarged in practice conditions.

Acknowledgements: This work has been carried out within the framework of National project KC08.04/11-15. The authors would like to thank the Ministry of Science and Technology for its financial support.

\section{References}

[1] Nguyen, T.B., Nguyen, K.K., Vu, X.P. (2005) A list of all plant species in Vietnam. Agricultural publishing house. 3: 478 .

[2] Brix H. (1994) Functions of macrophytes in constructed wetlands. Wat. Sci. Tech. 29: 71-78.

[3] Truong, T.N. \& Vo, T.K.H. (2010) Livestock wastewater treatment by Enydra fluctuans Lour and 
Eichhornia crassipes 10th December 2010 (http://www.thiennhien.net/2010/11/10/xu-ly-nuocthai-bang-rau-ngo-va-luc-binh/).

[4] Dang, X.N., Pham, H.S., Nguyen, P.C., Duong, H.D. (2005) Piggery wastewater treatment by UASB combined with aquatic plants. Journal of Biology. 27(1): 27-32.

[5] Prapa Sohsalam, Andrew Joseph Englande, Suntud Sirianuntapiboon. (2008) Seafood wastewater treatment in constructed wetland: Tropical case. Bioresource Technology. 99: 1218-1224.

[6] Rory Harrington and Robert McInnes. (2009) Integrated Constructed Wetlands (ICW) for livestock wastewater management. Bioresource Technology. 100(22): 5498-5505.

[7] Sim, C.H. (2003) The use of constructed wetlands for wastewater treatment. Water International - Malaysia Office. 24.

[8] Tran, V.T., Nguyen, T.K., Le, T.T.T., Vu, T.N. (2013) Removal of nitrogen and phosphorus from piggery wastewater by using surface flow system with reed. Nationwide Scientific Conference of Biotechnology. 1122-1127.

[9] Vincen Porphyre, Cirad, Nguyen, T.C., NIHA. (2006) Intensive pig farming, waste management and environmental protection, Prise publishing company.

[10] Vu, T.N., Tran, V.T., Nguyen, T.K., Dang, D.K. (2015) Using Eichhornia crassipes (Mart.) Solms for removing nitrogen and phosphorus in piggery wastewater after Biogas technology. Journal of Biology. 37(1): 53-59. 